\title{
Rihlah dalam Gerakan Dakwah Muhammadiyah
}

\author{
Hendi Rustandi $^{*}$, Nanih Mahendrawaty ${ }^{2}, \&$ Moch. Fakhruroji ${ }^{3}$ \\ ${ }^{1}$ Program Studi Komunikasi dan Penyiaran Islam, Program Pascasarjana, \\ UIN Sunan Gunung Djati, Bandung \\ 2Jurusan Manajemen Dakwah, Fakultas Dakwah dan Komunikasi, \\ UIN Sunan Gunung Djati, Bandung \\ ${ }_{2}^{2} J u r u s a n$ Ilmu Komunikasi, Fakultas Dakwah dan Komunikasi, \\ UIN Sunan Gunung Djati, Bandung \\ *Email: adalahhendi@gmail.com
}

\begin{abstract}
Muhammadiyah is an Islamic community organization engaged in da'wah. One othe Muhammadiyah missionary programs in West Java is the riblah program. This study aims to: (1). describing the concept of riblah in the West Java Mubammadiyah missionary movement, (2) describing the reason riblah was used as one of the Mubammadiyah preaching programs in West Java. (3). describe the implementation of the riblah program in the West Java Muhammadiyah missionary movement. This research uses a qualitative approach with descriptive methods in the form of case studies. The data in this study are the results of the interview. Data collection techniques in this study are observation, in-depth interviews, and documentation. The results of this study indicate that: 1). The concept of Riblah in the West Java Muhammadiyah Da'wah Movement is the missionary safari program of Mubammadiyah preachers to areas to exchange information, train militancy, socialize and consolidate organizations. 2). He made riblab as one of the da'wah programs because Muhammadiyah needed to develop an institutional da'wah network, from the regional, sub-district to village / kelurahan levels. 3). The implementation of the Muhammadiyah Da'wah Riblah West Java is carried out through the planning stage, the implementation of the program uses a variety of strategies so as to contribute to the availability of information about the potential, opportunities and challenges of the Muhammadiyah propaganda in West Java.
\end{abstract}

Keywords: Riblah, Da'wah, Muhammadiyah

\begin{abstract}
ABSTRAK
Muhammadiyah adalah organisasi kemasyarakatan Islam yang bergerak dibidang dakwah. Salah satu program dakwah Muhammadiyah di Jawa Barat adalah program rihlah. Penelitian ini bertujuan untuk: (1). mendeskripsikan konsep rihlah dalam gerakan dakwah Muhammadiyah Jawa Barat, (2) mendeskripsikan alasan rihlah dijadikan sebagai salah satu program dakwah Muhammadiyah Jawa Barat. (3). mendeskripsikan pelaksanaan program rihlah dalam gerakan dakwah Muhammadiyah Jawa Barat. Penelitian ini menggunakan pendekatan kualitatif dengan metode deskriptif berupa studi kasus. Data pada penelitian ini adalah hasil
\end{abstract}


wawancara. Teknik pengumpulan data dalam penelitian ini yakni observasi, wawancara secara mendalam, serta dokumentasi. Hasil penelitian ini menunjukan bahwa: 1). Konsep Rihlah dalam Gerakan Dakwah Muhammadiyah Jawa Barat adalah program safari dakwah mubaligh-mubaligh Muhammadiyah ke daerahdaerah untuk saling bertukar informasi, melatih militansi, sosialisasi dan konsolidasi organisasi. 2). Dijadikannya rihlah sebagai salah satu program dakwah karena Muhammadiyah perlu mengembangkan jaringan dakwah kelembagaan, dari tingkat daerah, kecamatan sampai ke desa/kelurahan. 3). Pelaksanaan Rihlah Dakwah Muhmadiyah Jawa Barat dilaksanakan melalui tahap perencaan, pelaksanaan program menggunakan strategi yang bervariasi sehingga memberikan kontribusi terhadap tersedianya informasi mengenai potensi, peluang dan tantangan dakwah Muhammadiyah di Jawa Barat.

Kata kunci: Rihlah, Dakwah, Muhammadiyah

\section{PENDAHULUAN}

Dakwah merupakan amaliah yang bersifat penting di dalam agama Islam, karena melalui dakwah, Islam dapat tersebar serta diterima oleh masyarakat. Dakwah berfungsi untuk menata kehidupan yang agamis menuju keharmonisan dan kebahagiaan masyarakat.

Urgensi dakwah sebagai sebuah aktivitas yang hukumnya wajib di dalam Islam sangat jelas, karena dasar hukum pelaksanaan dakwah terkodifikasi di dalam kitab suci al-Quran dan Hadis. Banyak ayat-ayat Alquran yang menerangkan tentang kewajiban umat Islam untuk berdakwah. Apabila dakwah dipahami sebagai ta'muruna bilma'ruf wa tanhauna 'anil munkar (memerintahkan kepada kebaikan dan melarang berbuat kemunkaran), maka akan kita temui di dalam al-Quran terdapat lafal ma'ruf sebanyak 38 kali dan lafal munkar sebanyak 16 kali. Semuanya memberi penjelasan bahwa betapa Islam memandang penting dan wajib dakwah itu dilakukan.

Dari tinjauan sosiologis, pengertian dakwah disebutkan sebagai upaya melakukan perubahan dari situasi masyarakat yang buruk menjadi baik, atau sebagai upaya menciptakan kondisi masyarakat kepada yang lebih baik sesuai dengan norma dan nilai-nilai ajaran Islam. Menghijrahkan manusia dari kebiasaan yang buruk kepada yang lebih baik, mengubah adat dan budaya yang salah (bertentangan dengan norma agama) kepada budaya yang benar.

Secara filosofis, orientasi dakwah adalah proses mempertemukan antara fitrah dan wahyu. Untuk menjadi muslim seutuhnya, diperlukan proses dakwah untuk menyampaikan, menyerukan dan mensosialisasikan nilai-nilai Islam dalam segala aspeknya yang bersumber dari Alquran dan asSunnah. Masyarakat Islam yang diwujudkan melalui sistem dakwah, adalah masyarakat yang berkembang dengan menjalankan syariat Islam secara 
integral dan komprehensif, yang menampilkan watak egalitarian, berkeadilan dan penuh kasih sayang.

Dakwah Islam senantiasa bersentuhan dengan realitas sosial yang mengitarinya. Oleh karenanya, ada dua kemungkinan yang mungkin terjadi, pertama, dakwah Islam mampu memberikan output (hasil atau pengaruh) terhadap lingkungan dalam arti memberi dasar filosofi, arah, dorongan dan pedoman perubahan masyarakat sampai terbentuknya realitas sosial baru yang diinginkan. Kedua, dakwah Islam dipengaruhi oleh perubahan masyarakat dalam arti eksistensi, corak dan arahnya. Ini berarti aktualitas dakwah ditentukan oleh sistem sosio kultural. Pada gilirannya, dakwah Islam bisa saja bersifat statis dan juga berlangsung secara dinamis.

Secara umum, aktivitas dakwah memiliki dua dimensi besar, yakni dimensi kerisalahan dan dimensi kerahmatan yang satu sama lain tidak dapat dipisahkan. Dalam konteks yang lebih luas, dimensi kerisalahan lebih identik dengan penyampaian teks agama sebagai ajaran ideal bagi manusia, sedangkan dimensi kerahmatan lebih merupakan upaya implementasi agama sebagai praktik sosial kebudayaan dalam kehidupan sehari-hari.

Pelaksanaan kewajiban dakwah, baik dalam dimensi kerisalahan maupun dimensi kerahmatannya, dapat dilakukan oleh perorangan (individu) maupun kelompok (lembaga, organisasi). Salah satu lembaga perancang dan pegelola gerakan dakwah di Indonesia, diantaranya adalah Muhammadiyah. Organisasi kemasyarakatan Islam terbesar di Indonesia ini, didirikan oleh K.H. Ahmad Dahlan pada tanggal 8 Zulhijjah $1330 \mathrm{H}$ bertepatan dengan tanggal 18 November 1912 di Yogyakarta. Muhammadiyah termasuk organisasi Islam tertua di Indonesia, dibandingkan dengan organisasi-organisasi Islam lainnya, seperti Nandlatul Ulama, Persis, Al-Irsyad dan sebagainya, yang lahir setelah Muhammadiyah ada.

Anggaran Dasar Muhammadiyah menyebutkan bahwa, organisasi Muhammadiyah merupakan gerakan dakwah Islam amr ma'ruf nabyi munkar, yang bertujuan untuk menegakkan dan menjunjung tinggi agama Islam sehingga terwujud masyarakat Islam yang sebenar-benarnya. Dalam melaksanakan kewajiban dakwahnya, Muhammadiyah telah merumuskan dan menyelenggarakan berbagai macam program. Pada tahap awal berdirinya, program dakwah Muhammadiyah sangat gencar memberantas masalah takhyul, bid'ah dan khurafat. Dakwah dengan model ini bertujuan untuk mengembalikan pemahaman dan pengamalan ajaran Islam berdasarkan petunjuk Alquran dan Sunnah.

Muhammadiyah menyadari bahwa, dakwah harus disampaikan secara tepat dan komunikatif agar benar-benar berhasil. Keberhasilan dakwah yang ditandai dengan pengamalan ajaran Islam pada aspek mental dan spritual, 
baru akan tercapai apabila metode yang digunakan dapat diterima masyarakat. Sebab dalam kajian dakwah, sangat perlu diperhatikan interaksi masing-masing unsur dakwah khususnya antara $d a^{\prime} i$ (penyampai), mad'u (masyarakat) serta metode yang digunakan.

Dalam menjalankan tugas dakwah ini, khususnya yang berkaitan dengan tabligh dan pembinaan ummat, Muhammadiyah membentuk sebuah badan yang bernama Majelis Tabligh. Majelis Tabligh ini merupakan badan pembantu Pimpinan Persyarikatan Muhammadiyah, yang mempunyai tugas pokok untuk memimpin pelaksanaan dakwah Islamiyah di bidang tabligh secara terencana, dan dalam program yang jelas meliputi seluruh aspek kegiatan dakwah yang tidak termasuk dalam bidang tugas majelis, atau badan-badan lainnya di lingkungan Persyarikatan Muhammadiyah.

Pada pelaksanaan tugas pokok dan fungsinya, Majelis tabligh Muhammadiyah menyelenggarakan berbagai program institusional dibidang dakwah, salah satunya yaitu riblah. Rihlah ini salah satu program dakwah yang berbentuk kunjungan (silaturahim) Majelis Tabligh Muhammadiyah dari pimpinan yang lebih tinggi di atsanya kepada pimpinan organisasi yang berada di level lebih rendah di bawahnya.

Dalam khazanah gerakan dakwah, istilah riblah ini tidak hanya dijumpai dalam program dakwah Muhammadiyah saja, salah satunya riblah dikenal sebagai perangkat tarbiyah pada gerakan dakwah Ikhwanul Muslimin. Gerakan dakwah yang diinisiasi oleh Imam Hasan al-Banna ini, mempunyai perangkat-perangkat tarbiyah yang jelas, tertata rapi dan mempunyai indikator yang jelas dalam membentuk militansi kaderkadernya.

Menilik riblah dari dimensi kebahasaan yang artinya perlawatan, perjalanan atau pelancongan seperti disebutkan tadi, maka riblah dalam konteks dakwah dapat dipahami sebagai penyelenggaraan program dakwah melalui serangkaian perjalanan, kunjungan atau pelancongan ke beberapa tempat untuk menyampaikan dakwah Islam. Pelaksanaan dakwah dengan model seperti itu dapat dijumpai pula dalam gerakan dakwah Jama'ah Tabligh. Jama'ah Tabligh adalah suatu kelompok dakwah, mempunyai cara dan metode yang berbeda dengan kelompok gerakan jama'ah lain pada umumnya. Mereka melakukan dakwah dengan cara keluar dari kampung tempat mereka tinggal, menuju kampung lain. Tinggal di masjid dan mendatangi rumah rumah warga untuk berdakwah. Model dakwah yang dilakukaan Jama'ah Tabligh ini dikenal dengan istilah khuruj.

Kata "khuruj" sendiri berasal dari bahasa Arab yaitu, "kharaja” yang artinya "keluar". "Keluar" yang di maksud adalah, suatu usaha amal untuk berdakwah guna mengajak manusia beribadah kepada Allah dan meninggalkan apa yang di larangNya. Secara ringkas, khuruj dalam Jama'ah 
Tabligh adalah, keluarnya seseorang dari lingkungannya untuk memperbaiki diri dengan belajar meluangkan sebagian harta serta waktunya dari kesibukannya di pekerjaan, keluarga dan urusan-urusan yang lain, demi meningkatkan iman dan amal shalih semata-mata karena Allah.

Berangkat dari gambaran-gambaran di atas, dapat ditanyakan untuk didalami, apakah program riblah dakwah Muhammadiyah itu dilakukan untuk mencetak kader-kader da'i dan mubaligh militan seperti halnya riblah yang dijumpai dalam tahapan-tahapan tarbiyahnya Ikwanul Muslimin, atau pelaksanaan dakwah pengabdian seperti dalam khuruj-nya Jama'ah Tabligh? Inilah yang melatari riblah sebagai salah satu program dakwah Muhammadiyah menarik untuk diteliti.

Alasan dilakukannya penelitian ini; pertama, Muhammadiyah sebagai salah satu organisasi kemasyarakatan Islam yang bergerak di bidang dakwah amar ma'ruf nahi munkar, memiliki model dan cara tersendiri dalam mentransformasi nilai-nilai ajaran Islam dalam kehidupan sosial kemasyarakatan. Hal tersebut terbukti dengan adanya istilah riblab dalam salah satu program dakwah Muhammadiyah. Kedua, kajian mengenai fenomena riblab dalam gerakan dakwah, memiliki relevansi dengan keilmuan dakwah umumnya, dan Komunikasi dan Penyiaran Islam khususnya. Ketiga, masih minimnya literatur mengenai riblah dalam gerakan dakwah amar ma'ruf nabi munkar-nya Muhammadiyah, sehingga dipandang perlu untuk menelitinya.

Fokus penelitian ini adalah program riblah dalam gerakan dakwah. penelitian ini bertujuan untuk 1). Mendeskripsikan konsep riblab dalam gerakan dakwah Muhammadiyah Jawa Barat. 2). Mendeskripsikan alasan rihlah dijadikan salah satu program dakwah Muhammadiyah Jawa Barat. 3). Mendeskripsikan pelaksanaan program riblah dalam gerakan dakwah Muhammadiyah Jawa Barat.

Pendekatan yang digunakan dalam penelitian ini adalah pendekatan kualitatif. Metode yang digunakan adalah metode deskriptif berupa studi kasus, yakni suatu rangkaian kegiatan ilmiah yang dilakukan secara intensif, terinci dan mendalam tentang suatu program, peristiwa, dan aktivitas, baik pada tingkat perorangan, sekelompok orang, lembaga, atau organisasi untuk memperoleh pengetahuan mendalam tentang peristiwa.

Penelitian yang relevan dalam penelitian ini daiantaranya, penelotian Mohd. Rafiq (2016) yang menyebutkan bahwa untuk mewujudkan keberhasilan dakwah Muhammadiyah telah merumuskan berbagai metode yang dianggap layak untuk diaplikasikan dalam kehidupan masyarakat. Ahmad Rifai (2011) menggambarkan dinamika gerakan organisasi yang dilakukan oleh Muhammadiyah kota Bandung. Mutohharun Jinan; Mubammadiyah Studies: Transformasi Kajian Tentang Gerakan Islam Di Indonesia. 
H. Rustandi, N. Mahendrawaty, \& M. Fakhruroji

Penelitian ini bertujuan menjelaskan tentang kajian-kajian terhadap Muhammadiyah. Tulisan ST Rajiah Rusdi yang berjudul "Peran Muhammadiyah (Konsep Pendidikan, Usaha-usaha di bidang Pendidikan dan Tokob). Penelitian Asep Daud Kosasih dan Suwarno tentang Pola Kepemimpinan Organisasi Muhammadiyah. Penelitian Arifin Zein tentang Internalisasi NilaiNilai Modernitas Dalam Gerakan Dakah Organisasi Mubammadiyah Di Aceh. Tulisan Robby H. Abror. Tentang Retbingking Mubammadiyah: Masjid, Teologi Dakwah dan Taubid Sosial (Perspektif Filsafat Dakwah)

\section{HASIL DAN PEMBAHASAN}

\section{Konsep Rihlah dalam Gerakan Dakwah Muhammadiyah Jawa Barat}

Pada dasarnya konsep merupakan abstraksi dari suatu gambaran ide, atau menurut Kant yang dikutip oleh Harifudin Cawidu yaitu gambaran yang bersifat umum atau abstrak tentang sesuatu. Fungsi dari konsep sangat beragam, akan tetapi pada umumnya konsep memiliki fungsi yaitu mempermudah seseorang dalam memahami suatu hal. Karena sifat konsep sendiri adalah mudah dimengerti, serta mudah dipahami.

Adapun konsep yang dimaksud dalam penelitian ini berdasarkan uraian di atas adalah, gambaran umum atau abstrak tentang program rihlah dalam gerakan dakwah Muhammadiyah.

Berdasarkan temuan penelitian mengenai konsep rihlah serta tujuannya menurut narasmber,

Menurut Dikdik Dahlan Lukman:

"Riblah adalah salah satu program Dakwah Pimpinan Persyarikatan Muhammadiyah berupa kunjugan dakwah yang dilakukan oleh Majelis Tabligh yang berada di level pimpinan peryarikatan yang lebih tinggi kepada pimpinan persyarikatan yang ada di bawahnya, Pimpinan Pusat mengunjungi Pimpinan Wilayah, Pimpinan Wilayah mengunjungi Pimpinan Daerah, Pimpinan daerah mengunjungi Pimpinan cabang dan pimpinan cabang mengunjugi Pimpinan Ranting".

Tujuan dilaksanakannya rihlah,

"Ada beberapa tujuan yang ingin dicapai dari program riblah dalam gerakan dakwah mubammadiyah diantaranya: Bersilaturabim dengan cara mengunjungi menyapa dan menggairahkan kehidupan bermubamadiyah di Daerah/Cabang//Ranting yang dikunjungi Menjadi ajang sosialisasi berbagai keputusan maupun perkembangan mutakbir Persyarikatan di tingkat Pusat maupun di Wilayah kepada pimpinan Daerah mubammadiyah yang dikunjungi. Melakukan pemetaan (a.l. analisa SWOT) terbadap dakwah/tabligh Persyarikatan di tingkat Daerah/Cabang/ Ranting baik secara kuantitatif maupun kualitatif'. 
Menurut Zulkarnain:

"Rikhlah dakwah muhammadiyah adalah lawatan atau kunjungan kerja pimpina persyarikatan yang berada di level atas kepada jamaah persyarikatan mubammadiyah dan simpatisan yang berada di lingkup pimpinan persyarikatan dibawahnya.

Tujuan rihlah,

"Konsolidasi dan dinamisasi program persayrikatan menyusun peta dakwah, memotret potensi, peluang dan tantangan dakwah Muhammadiyah, mensosialisasikan putusan-putusan atau fatwa-fatwa Mubammadiyah terutama yang berkaitan dengan sikap dan panduan pelaksaan Ibadab ".

Menurut Dachlan Ramli:

"Adalah safari dakwah mubaligh-mubaligh muhammadiyah ke daerah daerah untuk saling bertukar informasi, mengenai pelaksanaan tugas dakwah para pimpinan mubammadiyah, dan upaya mengenalkan organisasi mubammadiyah kepada masyarakat luas dengan cara lawatan, mengunjungi atau bersilaturabim.

Tujuan rihlah:

Sebagai upaya melatih militansi muballigh-mubaligh muhamadiyah. Penyebaran. Ajaran Islam dalam misi amar maruf nabi munkar kepada selurub kaum muslimin, terutama yang ada didaerab-daerah terpencil dan rawan kristenisasi

Dari pernyataan tersebut dapat dikatahui bahwa menurut $\mathrm{H}$. Dikdik Dahlan Lukman, M. Hum (ketua Majelis Tabligh Muhammadiyah Jawa Barat) bahwa Rihlah adalah salah satu program Dakwah Pimpinan Persyarikatan Muhammadiyah berupa kunjugan dakwah yang dilakukan oleh Majelis Tabligh yang berada di level pimpinan peryarikatan yang lebih tinggi kepada pimpinan persyarikatan yang ada di bawahnya, Pimpinan Pusat mengunjungi Pimpinan Wilayah, Pimpinan Wilayah mengunjungi Pimpinan Daerah, Pimpinan daerah mengunjungi Pimpinan cabang dan pimpinan cabang mengunjugi Pimpinan Ranting”.

Dari pernyataan tersebut, dapat dipahami bahwa konsep rihlah yang dilakukan oleh organisasi Muhammadiyah adalah sebagai strategi dakwah, bentuknya berupa penyampaian informasi mengenai kebijakankebijakan pimpinan Muhammadiyah, khususnya yang berkaitan dengan dakwah Muhammadiyan oleh struktur organisasi Muhammadiyah yang secara hierarkis berada diatas kepada level kepemimpinan Muhammadiyah yang berada di bawahnya.

Dalam persyarikatan Muhammadiyah, Rihlah juga bearti lawatan atau kunjungan kerja pimpinan persyarikatan Muhammadiyah yang berada di level atas kepada jamaah persyarikatan dan simpatisan yang berada di lingkup pimpinan persyarikatan dibawahnya. Para mubaligh- 
mubaligh muhammadiyah ke daerah daerah untuk saling bertukar informasi, mengenai pelaksanaan tugas dakwah para pimpinan Muhammadiyah, dan upaya mengenalkan organisasi Muhammadiyah kepada masyarakat luas dengan cara lawatan, mengunjungi atau bersilaturahim

'Rihlah Adalah safari dakwah Rihlah adalah salah satu program dakwah berupa Kunjungan Kerja Majelis Tablig kepada majelis tabligh Muhammadiyah di daerah untuk mengkonsolidasikan program-program majelis tabligh sehingga kewajiban dakwah dapat dilaksanakan oleh setiap Pimpina Muhamadiyah secara merata dan seragam".

Berdasarkan uraian diatas, peneliti mendapat informasi mengenai konsep rihlah dalam gerakan dakwah Muhammadiyah adalah sebagai serangkaian aktivitas penyampaian pesan atau informasi dengan cara mengunjungi, menyapa, berdiskusi, bertukar fikiran mengenai peluang dan tantangan dakwah Muhammadiyah. Konsep rihlah tersebut, apabila dilihat dari perspektif teori pesan dakwah, maka rihlah adalah sebagai proses penyampaian ide, gagasan, informasi, dan opini yang disampaikan oleh pimpinan persyarikatan Muhammadiyah yang berada dilevel kepemimpinan lebih tinggi sebagai komunikator, kepada struktur organisasi yang berada di bawahnya (komunikan).

Apabila ditinjau berdasarkan teori pesan dakwah, maka Rihlah sebagai aktivitas dakwah akan dikatakan berhasil atau efektif manakala pesan yanag disampaikan oleh da'i kepada mad'u dapat dipahami secara menyeluruh dan diungkapkan dengan tindakan nyata. Seorang da'i haruslah memahami karakter mad'u, mengetahui klasifikasi dan karakter mad'u agar pesan dakwah dapat diterima dengan baik.

\section{Alasan Rihlah dijadikan salahsatu program dalam gerakan dakwah Muhammadiyah Jawa Bara}

Dijadikannnya rihlah sebagai program dakwah gerakan dakwah Muhammadiyah tentu di latar belakangi gagasan yang menghendaki tercapainya tujuan dakwah. Dalam hal ini responden memberikan gambaran mengenai latar belakang dijadikannya rihlah sebagai salah satu program,

Menurut Dikdik Dahlan Lukman:

"Selain secara normatif melaksanakan keputusan Pimpinan Wilayah Muhammadiyah Jawa Barat tentang Program kerja Majelis Tabligh, riblah juga dilaksanakan atas dasar keputuaan rapat kerja Majelis Tabligh PWM Jawa Barat yang diantaranya melaksanakan riblah dakwah sebagai salah satu program konsolidasi organisasi, pembinaan daerah-daerah.Selain itu PWM Jawa Barat masih memiliki PR (pekerjaan rumah) dalam hal 
pembentukan Derah, cabang dan ranting. Saat ini PWM Jawa Barat baru memiliki . 51,4\%..\% jumlah Pimpinan Cabang dari selurub jumlah kecamatan yang ada di Jawa Barat. Tentunya setiap pimpimpinan daerah juga memiliki kewajiban Institusi yang sama di daerabnya masing-masing perlu mendorong percepatan pembentukan cabang dan ranting di setiap kecamatan dan desa/kelurahan.

Menurut Zulkarnain:

"Pimpinan wilayah Muhammadiyah Jawa Barat memerlukan informasi objektif dan otentik mengenai kondisi persyarikatan di daerab".

Menurut Dachlan Ramli:

'Dalam melaksanakan dakwah Muhammadiyah memerlukan peta dakwah, berapa jumlah muballigh di daerah, berapa jumlah masjid, berapa jumlah jamaah binaan muhammadiyah di daerah, untuk menjawab pertanyaanpertanyaan itu maka perlu dikakukan riblab dakwah".

Menurut Didin Nasrudin:

"Karena mubammadiyah sebagai organisasi dakwah yang berkewajiban untuk menyebar luaskan ajaran islam dan melaksanakannya dalam kehidupan sehari-hari, maka riblah dilakukan sebagai salah satu model dakwah muhammadiyah, atau metode dakwah muhammadiyah".

Dari uraian tersebut dapat diketahui secara umum responden mengutarakan alasan Rihlah dijadikan sebagai salah satu program dalam gerakan dakwah adalah alasan normatif, yaitu karena alasan organisatoris, kewajiban melaksanakan putusan organisasi. Hal ini dapat dilihat dari kutipan wawancara dengan Ketua majelis Tabligh PWM Jawa Barat, H. Dikdik Dahlan Lukman, bahwa selain program rihlah tersebut telah ditetapkan sebagai salah satu program yang harus dilaksanakan, rihlah juga diselenggarakan untuk memenuhi kebutuhan organisasi dalam hal pemenuhan struktur pimpinan organisasi persyarikatan Muhammadiyah dari daerah, cabang hingga ranting di seluruh Jawa Barat.

Apabila alasan dijadikannya Rihlah sebagai salah satu program dakwah di Pimpinan Wilayah Muhammadiyah Jawa Barat, salah satunya untuk pengembangan organisasi dan merupakan bagian dari tugas organisasi, maka keberhasilan penyelenggaraan rihlah dalam gerakan dakwah Muhammadiyah Jawa Barat ini dapat dilihat Teori organisasi.

Teori organisasi adalah suatu teori yang mempelajari kinerja dalam sebuah organisasi. Salah satu kajian teori organisasi diantaranya membahas tentang bagaimana sebuah organisasi menjalankan fungsi dan mengaktualisasikan visi dan misi organisasi tersebut. Selain itu, dalam teori ini dipelajari bagaimana suatu organisasi memengaruhi dan dipengaruhi oleh orang-orang yang ada di dalamnya, maupun yang berada di lingkungan kerja organisasi tersebut. 
Menurut Lubis dan Husein teori organisasi adalah sekumpulan ilmu pengetahuan yang membicarakan mekanisme kerjasama dua orang atau lebih secara sistematis untuk mencapai tujuan yang telah ditentukan. Teori organisasi merupakan sebuah teori untuk mempelajari kerjasama pada setiap Individu.

Dengan demikian, maka dapat dilihat bahwa rihlah sebagai aktivitas komunikasi organisasi yang dilakukan untuk mencapai tujuan organisai. Karena Muhammadiyah tujuannya adalah dakwah, maka tentunya komunikasi organisasi yang dilakukan Muhammadiyah melalui program rihlah adalah komunikasi dakwah.

Komunikasi organisasi itu sendiri adalah pengirim dan penerima berbagai pesan organisasi didalam kelompok formal maupun informal di suatu organisasi. bila organisasi semakin besar dan kompleks maka akan mengakibatkan semakin kompleks pula proses komunikasinya. Organisasi kecil yang anggotanya hanya tiga orang, proses komunikasi yang anggotannya seribu orang menjadi komunikasinya sangat kompleks.

Komunikasi organisasi dapat bersifat formal dan informal. Komunikasi formal adalah komunikasi yang disetujui oleh organisasi itu sendiri dan sifatnya berorientasi kepentingan organisasi. isinya berupa cara kerja di dalam organisasi, produktivitas, dan berbagai pekerjaan yang harus dilakukan dalam organisasi. misalnya: memo, kebijakan, pernyataan, jumpa pers, dan surat-surat resmi. Adapun komunikasi informal adalah komunikasi yang disetujui secara sosial. Orientasinya bukan pada organisasi, tetapi lebih kepada anggotannya secara individual.

Menurut Gold Haber yang dikutip oleh Arni Muhammad dalam bukunya Komunikasi Organisasi ia menyatakan bahwa, komunikasi organisasi adalah proses menciptakan dan menukar pesan dalam suatu jaringan hubungan yang saling tergantung satu sama lain untuk mengatasi lingkungan yang sering berubah-ubah. Komunikasi organisasi mempunyai peranan penting dalam memadukan fungsi-fungsi manajemen dalam suatu perusahaan yaitu :

a. Menetapkan dan menyebarluaskan tujuan perusahaan

b. Menyusun rencana untuk mencapai tujuan yang telah ditetapkan

c. Melakukan pengorganisasian terhadap sumber daya manusia dan sumber daya lainnya dengan cara efektif

d. Memimpin, mengarahkan, memotivasi dan menciptakan iklim yang menimbulkan keinginan orang untuk memberikan kontribusi

e. Mengendalikan prestasi. 


\section{Pelaksanaan Program Rihlah dalam Gerakan Dakwah Muhammadiyah Jawa Barat}

Untuk mengetahui pelaksananan Rihlah dalam gerakan Dakwah Muhammadiyah Jawa Barat ini diajukan tiga pertanyaan kepada responden berdasarkan aspek pertanyaan sebagai berikut;

a Prosedur pelaksanaan Rihlah dalam gerakan dakwah Muhammadiyah

b Strategi pelaksanaan Rihlah dalam gerakan dakwah Muhammadiyah

c Hambatan dalam pelaksanaan program Rihlah dalam gerakan dakwah Muhammadiyah

d Kontribusi pelaksanaan program rihlah dalam gerakan dakwah Muhammadiyah

Prosedur merupakan suatu proses, langkah-langkah atau tahapantahapan dari serangkaian kegiatan yang saling berhubungan satu dengan yang lainnya, prosedur juga biasanya melibatkan beberapa orang dalam suatu departmen di dalam perusahaan.

Menurut Mulyadi (2008: 5) prosedur adalah suatu urutan kegiatan klerikal, biasanya melibatkan beberapa orang dalam suatu departemen atau lebih, yang dibuat untuk menjamin penanganan secara seragam transaksi perusahaan yang terjadi berulang - ulang. Sedangkan menurut Azhar (2000: 195) juga menjelaskan bahwa Prosedur adalah rangkaian aktivitas atau kegiatan yang dilakukan secara berulang dengan cara yang sama.

Dari kedua definisi prosedur diatas dapat disimpulkan bahwa prosedur merupakan suatu urutan kegiatan klerikal (bersangkutan) yang biasanya melibatkan beberapa orang dalam satu departemen atau lebih, yang disusun untuk menjamin penanganan secara seragam terhadap transaksi perusahaan yang terjadi berulang-ulang. Pada umumnya pekerjaan klerikal terdiri dari penulisan, pemberian kode, pembandingan, penggandaan, pemilihan, perhitungan, dan pembuatan daftar.

Dari data hasil temuan penelitian, narasumber memberikan keterangan mengenai prosedur pelaksanaan rihlah dalam gerakan dakwah Muhammadiyah sebagai berikut:

Narasumber pertama, Dikdik Dahlan Lukman memberikan keterangan yang cukup jelas terkait prosedur teknis pelaksanaan program rihlah:

"Karena Riblah secara resmi merupakan program dakwah yang telah diputuskan, maka Majelis tabligh sebagai pelaksana program riblah memiliki otoritas untuk menyelenggarakan dan menentukan jadwal kunjungan (riblab) kepada daerah-daerah mubammadiyah yang akan dikunjungi. Untuk prosedur pelaksanana riblah, Majelis Tabligh Pimpinan Wilayah memberikan surat pemberitabuan terlebih dabulu mengenai rencana pelaksaan riblah kepada majelis tabligh di daerah. Pimpinan daerah menyediakan 
tempat dan akomodasi kegiatan riblah, menginventarisir kepesertaan riblah. Sementara Pimpinan Wilayah menyusun materi-materi pokok yang akan disampaikan dalam kegiatan riblah, selanjutnya materi-materi pokok itu dikembangkan dalam hearing atau diskusi dengan pimpinan daerah. Mengidentifikasi potensi peluang dan tantangan dakwah persyarikatan di daerah, dan selanjutnya hasil dari kegiatan riblab tersebut dijadikan rekomendasi untuk disampaikan kepada pimpinan wilayah mubamamadiyah Jawa Barat".

Narasumber kedua yaitu Zulkarnain, memberikan penjelasan mengenai prosedur pelaksanaan rihlah sebagai berikut:

"Pelaksanan riblah dakwah secara administratif berada dalam kewenangan Majelis Tabligh, mereka menyusun penjadwalan, menyiap materi dan membagi personil yang akan melaksanakan kunjungan dakwah ke daerah. Majelis tabligh juga mebnetuk tim atau membagi personalia Tim untuk mengunjungi daerah daerah secara terjadwal".

Narasumber ketiga Dahlan Ramli, membeikan penjelasanan mengenai prosedur pelaksanaan rihlah sebagai berikut:

'Dulu riblah dakwah itu dilakukan oleh perorangan dai mubammadiyah, karena sekarang sudah jadi program majelis tabligh, maka prosedur pelaksanan riblah itu diatur oleh majelis tabligh"

Narasumber keempat Didin Nasrudin, memberikan penjelasan mengenai prosedur pelaksanaan rihlah sebagai berikut:

"Diatur jadwal, dibagi tim dan disebar tim, kalau tim nya tidak memenubi sejumlah daerah yang ada, maka setiap daerah dibagi zona. Misalnya zona 1. Kota Bandung, Kab. Bandung, Kota Cimahi dan Kabupaten Bandung Barat. Pimpinan Daerah Mubammadiyah yang termasuk pada zona 1 berkumpul di suatu daerah, kemudian ditugasi personalia di Majelis Tablig Wilayah jawa Barat yang bertugas mengunjungi daerah di zona 1 tersebut"

Secara garis besar, prosedur pelaksanaan Rihlah dalam gerakan dakwah Muhammadiyah Jawa Barat adalah:

1) Membuat kebijakan program yang diputuskan dalam musyawarah kerja, musyawarah tersebut menghasilkan keputusan diantaranya, rihlah sebagai salah satu program kerja organisasi yang harus dilaksanakan dan dipertanggungjawabkan pelaksanaannya, dievulauasi hasilnya dan disampaikan rekomendasinya kepada Pimpinan Wilayah Muhammadiyah Jawa Barat untuk ditindaklajuti.

2) Mengalokasikan waktu pelaksanaan, yaitu mengatur jadwal,

3) Menyiapkan materi-materi pokok yang akan disampaikan

4) Menginventarisasi tim, dan tugas kerja tim yang akan diutus melakukan perjalanan lawatan rihlah

5) Membagi penugasan tim. 
6) Mensosialisasikan jadwal, biasanya dibagi zonasi, mengingat Jawa Barat begitu luas, sebaran Pimpinan Daerah Muhammadiyah di Jawa Barat juga cukup banyak. Dengan dibagi zonasi tersebut, maka pelaksanaan rihlah akan lebih epesien. Artinya efesien dalam ukuran waktu, sumberdaya (tim) maupun biaya akomodasi penyelenggaraan program rihlah.

7) Melaksanakan perjalanan rihlah

8) Mencatat seluruh temuan di lapangan, potensi, peluang dan tantangan dakwah

9) Menyusun laporan dan evaluasi

10) Merekomendasikan hasil rihlah kepada PWM

11) Menindaklanjuti hasil rihlah dalam forum refresing muballigh

Hambatan. Kamus Besar Bahasa Indonesia (1990 : 235), menjelaskan yang dimaksud dengan penghambat adalah hal yang menjadi penyebab atau karena hanya tujuan atau keinginan tidak dapat diwujudkan. Jadi, penghambat yang dimaksud dalam penelitian ini adalah hal-hal yang menyebabkan terhambatnya yang dihadapi lansia dalam memperoleh pelayanan kesehatan dan pelayanan sosial.

Ada banyak problematika dan hambatan-hambatan yang dihadapi oleh para pelaku dakwah, hal itu melahirkan dua sikap dari para juru dakwah, pertama menganggap bahwa hambatan dalam berdakwah merupakan sebuah sunatullah yang harus dihadapi dengan keteguhan iman dan kapasitas diri, sedang kelompok kedua menjadikannya sebagai tantangan sekaligus ujian dan menerima apa adanya. Secara umum menurut kajian ilmu komunikasi, hambatan tersebut pada dasarnya sama dengan hambatan dalam komunikasi dakwah.

Dalam proses komunikasi dakwah seringkali banyak terjadi hambatan yang kadang-kadang tidak bias kita duga atau kita ramalkan, karena obyek dakwah sifatnya dinamis selalu berubah, begitu pula sering terjadi factor-faktor lain seperti misalnya, cuaca, kondisi tempat, suasana lingkungan dan lain sebagainya. Hambatan konunikasi dakwah dapat mempengaruhi tujuan dan harapan yang diinginkan oleh komunikator, oleh karena itu untuk memperkecil kegagalan komunikasi, para juru dakwah sebaiknya terlebih dahulu memahami dan mengantisipasi beberapa faktor yang menjadi hambatan komunikasi tersebut Sebagaimana dijelaskan Deddy Mulyana dalam Bukunya " Ilmu Komunikasi “ (2007) : menyebutkan antara lain :

1) Hambatan Semantis, hambatan ini muncul dari diri komunikator dalam hal ini juru dakwah (mubaligh), yaitu adanya gangguan dalam penggunaan bahasa, misalnya dalam pengucapan kalimat, kurang fasih, ketidak-tepatan dalam menggunakan bahasa asing. Hambatan semantic 
ini bila tidak dihilangkan akan mengakibatkan dan menimbulkan kesalahan pengertian, kesalahan tafsir (misunderstanding dan misinterpretation) yang pada akhirnya menimbulkan mis-communication. Gangguan semantik juga banyak disebabkan oleh factor antropologis, misalnya suatu kalimat dan kata yang sama dapat dimaknai secara berbeda bahkan saling bertentangan disebabkan oleh latar belakang budaya dan norma yang berbeda baik suku maupu bangsa.

2) Hambatan Psikologis, adalah hambatan yang dialami oleh komunikator dakwah, misalnya yang dihadapi sebagai audience salah satunya adalah mantan pacarnya atau calon mertua, demikian juga hal-hal yang sedang dialami oleh dirinya, misalnya sedang duka, sedih dan kurang menguasai materi dakwah dan lain-lain. Hambatan psikologis juga disebabkan oleh factor luar dari komunikator, misalnya audiencenya sedang dilanda sedih, cemas, marah, iri dan berprasangka negatif terhadap koimunikatornya, hal tersebut akan menjadi hambatan yang serius bagi komunikatornya.

Dalam peristiwa komunikasi dakwah, hambatan psikologis hendaknya harus tidak ada, karena sangt berkaitan dengan kredibilitas dan ketauladanan seorang juru dakwah, komunikator dakwah harus menjadi panutan dan soritauladan serta memiliki moralitas yang tinggi. Bila hal tersebut tidak dimiliki maka akan menjadi hambatan yang paling serius, bahkan bisa jadi seorang juru dakwah akan menjadi obyek perolok-olokan dan kecaman dari para jama'ahnya. Sebgaimana disebutkan dalam Al-Qur'an Surat Ashaf ayat 2-3 dan Surat Al-Baqarah ayat 44, :

"Hai orang-orang yang beriman, mengapa kamu mengatakan apa yang tidak kamu kerjakan ?, amat besar kemurkaan di sisi Allah bahwa kamu mengatakan yang kamu sendiri tidak mengerjakannya. " (As-Shaf 2-3).

"Mengapa kamu menyurub orang lain mengerjakan kebaikan, sedang kamu melalikan kewajiban diri kamu sendiri, padah kamu membaca Al-Kitab apakan kamu tidak berfikir? (Al-Baqarah 44).

3) Hambatan Mekanis, yaitu hambatan yang berkaitan dengan saluran atau media perangkat komunikasi yang digunakan oleh komunikator seperti gangguan alat komunikasi seperti alat pengeras suara, gangguan alat listrik yang macet atau padam dan lain-lain. Hambatan tersebut seringkali kita jumpai dalam peristiwa komunikasi dakwah, sehingga sangat menghambat proses dan tujuan komunikasi.

4) hambatan Ekologis, yaitu hambatan yang berkaitan dengan lingkungan komunikasi yaitu hal-hal yang berkaitan dengan peristiwa alam, serperti misalnya gangguan suara petir, gunung meletus, banjir, hujan yang sangat lebat, suara pesawat terbang, suara mobil, dan kegaduhankegaduhan lainnya. Untuk kelancaran proses komunikasi dakwah 
sebaiknya direncanakan dan dipersiapkan semaksimal mungkin sehingga hambatan dan gangguan komunikasi dakwah sedikit mungkin dapat dihindari.

5) Hambatan Sosioantropologis, yaitu hambatan yang berkaitan dengan aspek konidisi masyarakat yang memiliki tingkat keragaman yang tinggi, termasuk menghadapi kelas-kelas sosial, misalnya masyarakat kelas rendahan, kelas menengah dan kelas atas, termasuk didalamnya karakteristik masyarakat yang kritis, yang apatis dan yang dinamis. Sedang hambatan yang berkaitan dengan antropologis , misalnya adanya perbedaan kultur, perbedaan tradisi adat istiadat dan norma yang berlaku dimasyarakat. Bila komunikator dakwah tidak memahami faktorfaktor tersebut, maka proses dan tujuan serta missi dakwahnya tidak akan tercapai.

Adapaun hambatan yang sering dialami dalam pelaksanaan proram rihlah dalam gerakan Dakwah Muhammadiyah sebagaimana dijelaskan narasumber Dahlan Lukaman,

"Hambatan yang sering kali dibadapi pada setiap penyelenggaraan program riblab adalah keterbatasan waktu luang para pengoiat persyarikatan untuk turut serta dalam riblah ini. hal ini memang dapat dipahami, karena para pengurus persyarikatan ini memiliki kesibukan masing-masing. Selain keterbatasan keperansertaaan para pengurus juga, yang juga terpenting adalab keterbatasan dana dan daya untuk. menyelenggarakan program riblab itu. Hambatan lainnya juga sering kali di dapat dari penyelenggaraan riblah yang selama ini dilakukan Majlelis Tabligh PWM Jawa Barat adalah sinkronisasi waktu antara jadwal para pimpinan majelis wilayah dengan daerah, sehingga percepatan dan persebaran kegiatan riblah ini sering kali lamban. Ditambah program dakwah lainnya juga yang harus diselesaikan dalam satu periode ini. program dakwah majelis Tabligh PWM Jawa Barat juga kan bukan banya riblah. Ada kaderisasi muballigh, pengajian rutin bulanan di tingkat wilayah yang harus dikelola, penyusunan tata kelola masjid mubammadiyah sejawa barat yang segera diselesaikan dan disosialisasikan ke selurub daerah cabang dan ranting seluruh jawa barat.

Menurut Zulkarnain:

"Kurangya personalia yang memeliki kesediaan waktu untuk turut serta mengikuti kegiatan riblah. Mungkin juga kurang dana, sehingga kita tidak dapat menjamin dan memberikan insentif yang wajar kepada para pelaksana program riblah ini"

Menurut Dahlan Ramli:

"Tidak semua orang welcome dengan kunjungan dakwah mubammadiyah, sehingga sering kali riblah ini banya diikuti oleh segelintir orang. Padhal kita 
sudah jauh-jauh datang, menyiapkan segala sesuatu, mengorbankan waktu, materi dan sebagainya"

Menurut Nasrudin:

"Sumber daya dan sumber dana masih belum memadai untuk dilakukan riblah secara massif di selurub jawa bara"

Dari hal-hal tersebut diatas, baik yang menyangkut probelematika Komunikator dakwah, metodologi dan berbagai hambatan yang dihadapi dalam proses komunikasi dakwah maka diperlukan sebuah kesiapan secara terencana, sehingga pelaksanaan dakwah Islam akan dapat berhasil sesuai dengan tujuan yang diharapkan. Diperlukan strategi yang tepat sebagai solusi dari hambatan tersebut.

Strategi. Prosedur pelaksanaan rihlah dalam gerakan dakwah Muhammadiyah tentu memerlukan strategi untuk mencapai tujuan rihlah tersebut. Istilah strategi secara etimologis berasal dari bahasa Yunani "stratego" yang berarti merencanakan pemusnahan musuh lewat penggunaan sumber-sumber yang efektif. Strategi sering diidentikan dengan taktik. K. Andrew dikutip Mudrajat Kuncoro mengatakan bahwa strategi adalah pola sasaran, tujuan, dan kebijakan umum untuk meraih tujuan yang telah ditetapkan.

Dalam literaur lain dijelaskan bahwa strategi sendiri maknanya adalah rencana yang cermat mengenai kegiatan untuk mencapai sasaran khusus. Sedangkan Strategi dakwah artinya metode, siasat, taktik atau manuver yang dipergunakan dalam aktifitas (kegiatan) dakwah.

Strategi yang digunakan oleh suatu organisasi sangat ditentukan oleh tujuan yang hendak dicapai, serta kondisi yang ingin diciptakan. Strategi yang dipakai dalam memecahkan persoalan tertentu sudah pasti berbeda dengan strategi yang diterapkan untuk memecahkan persoalan lain.

Beberapa dari pengertian strategi di atas dapat ditarik kesimpulan, bahwa strategi merupakan konsep atau kerangka berpikir, sedangkan metode merupakan penerapan konsep tersebut. Jika strategi dikaitkan dengan dakwah maka dapat diartikan sebagai proses menentukan cara dan daya untuk menghadapi sasaran dakwah dalam situasi dan kondisi tertetu guna mencapai tujuan dakwah secara optimal. Dengan kata lain, strategi dakwah adalah siasat, taktik yang ditempuh untuk mencapai tujuan dakwah.

Strategi. Untuk mencapai keberhasilan dakwah secara maksimal, maka diperlukan berbagai faktor penunjang, diantaranya adalah strategi dakwah yang tepat sehingga dakwah tepat sasaran. Adapun strategi pelaksanaan rihlah dalam gerakan dakwah Muhammadiyah sebagaimana diuraikan oleh narasumber, Menurut Dahlan Ramli: 
"Strategi yang dilakukan dalam riblah terutama dulu di tabun 60-70an menggunakan metode GJ DJ, yaitu gerakan jamaah dan dakwah Jamaah. Gerakan jamaah adalah mengkonsolidasi jamaah untuk melaksanakan ajaran Islam, menjalin kerjasmaa ukhuwah Islamiyah dll. Dan dakwah Jamaah adalah menyelenggarakan forum-forum pengajian jamah-jamaah di setiap daerah"

Menurut Didin Nasrudin:

"Strategi pelaksanaan riblah adalah dengan cara menyelenggarakan kegiatan secara gebyar, pengajian umum, diskusi, sholat berjamaah atau bakti sosial". Strategi dakwah dalam rihlah sebagai gerakan dakwah Muhammadiyah tersebut telah menggunakan starategi yang tepat. Hal ini sesuai dengan apa yang disampaikan Samsul Munir Amin (2009) tentang asas dakwah. Strategi dakwah dalam rihlah sebagai gerakan dakwah Muhammadiyah telah memperhatikan beberapa asas dakwah, diantaranya adalah:

1) Asas filosofis: Asas ini membicarakan masalah yang erat hubungannya dengan tujuan-tujuan yang hendak dicapai dalam proses atau aktivitas dakwah. Program rihlah dalam gerakan dakwah Muhammadiyah sendiri memiliki tujuan yang jelas yakni mendakwahkan ajaran Islam.

2) Asas kemampuan dan keahlian da'i (Achievment and professionalis): Asas ini menyangkut pembahasan mengenai kemampuan dan profesionalisme da'i sebagai subjek dakwah. Dalam program rihlah gerakan dakwah Muhammdiyah sudah menjadi harga mutlak bahwa kemampuan dan keahlian para dai menjadi syarat penting terlaksananya dakwah. Halmini dikarenakan dalam program rihlah pasti mengunjungi daerah-daerah yang kebudayaanya kompleks, disaat itulah diperlukan kemampuan dai untuk melakukan dakwah yang merangkul segala macam perbadaan.

3) Asas sosiologi: Asas ini membahas masalah-masalah yang berkaitan dengan situasi dan kondisi sasaran dakwah. Misalnya politik pemerintah setempat, mayoritas agama disuatu daerah, filsofis sasaran dakwah, sosio kultural sasaran dakwah dan sebagainya.

4) Asas psikologi: Asas ini membahas masalah yang erat hubungannya dengan kejiwaan manusia. Seorang da'i adalah manisia, begitu pula sasaran dakwahnya yang memiliki karakter unik dan berbeda satu sama lain. Pertimbangan-pertimbangan masalah psikologis harus diperhatikan dalam proses pelaksanaan dakwah

5) Asas aktivitas dan efisien: Maksud asas ini adalah didalam aktivitas dakwah harus diusakan keseimbangan antara biaya, waktu, maupun tenaga yang dikeluarkan dengan pencapian hasilnya. Sehingga hasilnya dapat maksimal. Dengan mempertimbangkan asas-asas diatas, seorang 
da'i hanya butuh memformulasikan dan menerapkan strategi dakwah yang sesuai dengan kondisi mad'u sebagai objek dakwah.

Sebanarnya, informasi-informasi yang berkaitan dengan kebijakan kelembagaan Muhammadiyah, terlebih informasi itu disampaikan dari struktur yang berada di atas kepada kepemimpinan Muhammadiyah yang ada dibawahnya, bisa saja disampaikan melalui beberapa media, baik media yang berada di internal Muhammadiyah, Surat, Majalah, telefon atau telegram dan media lain yang saat ini semakin mudah untuk digunakan sebagai alat menyampaikan informasi, namun Muhammadiyah tetap merasa perlu, menyampaikan informasi ini dengan cara mengunjungi penerima informasi secara langsung dalam program rihlah terlebih terhadap masyarakat yang belum tersentuh teknologi.

Kehidupan masyarakat Islam dalam perkembangan sekarang ini mengalami perubahan-perubahan sosial yang sangat cepat. Berkembangnya budaya populer, materialistik dan pragmatis telah menggeser semangat beragama dalam diri umat Islam. Dakwah sebagai instrumen keagamaan untuk mempertahankan kondisi kehidupan umat Islam yang sesuai dengan nilai dasar Islam, harus terus beradaptasi dengan situasi tersebut.

Strategi dalam praktiknya merupakan pola tujuan, kebijakan, program, tindakan, keputusan atau merupakan alokasi sumber daya yang menjadi dasar bagi suatu organisasi dalam mengkonstruk sesuatu yang mesti dikerjakan.

Dalam kaitannya dengan strategi rihlah yang dilakukan oleh Pimpinan Wilayah Muhammadiyah Jawa Barat, maka program ini sebagai upaya perluasan misi persyarikatan Muhammadiyah yang dilakukan untuk menjembatani organisasi dengan lingkungannya. Lingkungan organisasi yang dimaksud adalah struktur pimpinan Muhammadiyah di bawahnya dan lingkungan sekitar atau jamaah dan simpatisannya.

Rihlah dakwah Muhammadiyah pada prinsipnya adalah sebagai upaya menyampaikan pesan-pesan dan informasi-informasi kelembagaan persyarikatan. Penyampaain pesan dan informasi tersebut dilakukan dengan cara ceramah, dialog, dan presentasi program dakwah yang harus dicapai selama satu periode kepengurusan. Dalam rihlah tersebut juga disampaikan hal-hal yang berkaitan dengan ideologi dakwah muhammadiyah, berupa materi-materi keagamaan atau fatwa-fatwa persyarikatan tentang persoalanpersoalan keagamaan, sehingga jika terjadi dinamika, perselisihan, perbedaan pendapat mengenai soal-soal tertentu, seperti urusan fiqh atau hal-hal furuiyah lain yang berkaitan dengan pelaksananan syariat, ibadah dan muamalah. Pimpinan persyarikatan Muhammadiyah di daerah memiliki rujukan resmi yaitu keputusan tarjih muhammadiyah. Selain itu rihlah dakwah dilakukan juga sebagai upaya mendorong peningkatan kompetensi 
muballigh muhammadiyah di daerah. Peningkatan kompetensi muballigh ini dilakukan dengan cara membekali muballigh dengan berbagai materimateri tabligh dan prinsip-prinsip dakwah amar ma'ruf nahi munkar

Kontribusi. Secara teoritis kontribusi diartikan sebagai sumbangsih atau peran, atau keikutsertaan seseorang dalam suatu kegiatan tertentu. dalam kaitannya dengan rihlah sebagai program dakwah Muhammadiyah memiliki kontribusi baik secara kelembagaan terutama kontribusi di masyarakat sebagai objek dakwah. Berdasarkan temuan penelitian dapat dikatahui bahwa kontribusi program rihlah dalam gerakan dakwah Muhammadiyah.

Menurut Dikdik Dahlan Lukman:

"Selain mengkonsolidasikan prorgarm-program dan keputusan Mubumammadiyah Jawa Barat ke seluruh daerah, mendinamisasi dan menggairabkan kehidupan bermuhammadiyah di Jawa Barat, program Riblah ini memberikan konstribusi penting bagi pengembangan dakwah mubammadiyah. Karena dari program riblab ini kita dapat menyajikan peta dakwah Muhammadiyah Jawa Barat, menambah jumlah muballigh dan dai mubammadiyah, beserta meningkatkan kompetensinya, menambah jumlah cabang dan ranting di daerah, sebingga keberadaan mubammadiyah dapat dirasakan manfaatnya oleh masyarakat luas, bukan halnya terpenubinya kebutuhan layanan dakwah masyarakat, dengan terselenggaranya pengajianpengajian tetapi juga dalam halpendidikan, kesehatan, sosial ekonomi, karena mubammadiyah berdakwah tidak hanya pada sektor tabligh dan taklim saja" Menurut Zulkarnain:

'Dengan program riblah ini memberikan konstribusi pada tersedianya peta dan pemetaan potensi persyarikatan mubammadiyah di Jawa Barat. Tersampaikannya program-program dan kebijakan Pimpinan Wilayah Mubammadiyah Jawa baret ke daerah-daerab"

Menurut Dahlan Ramli

"Memberikan masukan kepada penyusunan program majelis Tabligh sebagai corong dakwah Muhammadiyah".

Menurut Didin Nasrudin:

"Tersedianya data demografi dan monografi dakwah Muhammadiyah, dan optimalisasi peran majelis tablihg sebagai lembaga pembantu pimpinan persyarikatan, yang memerankan fungsinya sebagai laboratorium dakwah Muhammadiyah".

Dari pendapat-pendapat tersebut jelas bahwa kontribusi rihlah terhadap perkembangan dakwah Muhammadiyah sangat penting. Program rihlah memiliki kontribusi terhadap perkembangan sosial diantaranya: Kontribusi bagi para partisipasn rihlah,kontribusi bagi organisasi, dan kontribusi bagi masyarakat yang menjadi objek rihlah. 
Para partisipan rihlah biasanya terdiri dari anggota majelis tablih yang mengagas program serta para muballigh yang akan memnyampaikan pesan dakwah. Kontribusi ini sesuai dengan teori komunikasi persuasif dan teori komunikasi dakwah dimana menurut buku Komunikasi Dakwah yang ditulis oleh Wahyu Ilaihi, menyatakan bahwa komunikasi persuasif adalah komunikasi yang bertujuan untuk mengubah sikap, pendapat, dan perilaku. Istilah persuasif bersumber dari bahasa latin yaitu "persuasion" yang berarti membujuk, mengajak atau merayu. Rihlah ini dalam pelaksanaanya memberikan kontribusi semakin mengembangkan kemampuan berkomunikasi para mubaligh dalam berdakwah khusunya menghadapi masyarakat yang memiliki kultur sosial berbeda.

Persuasif bisa dilakukan secara rasional dan secara emosional. Dengan cara rasional, komponen kognitif pada diri seseorang dapat dipengaruhi. Aspek yang dipengaruhi berupa ide ataupun konsep. Persuasif yang dilakukan secara emosional, biasanya menyentuh aspek afeksi, yaitu hal yang berkaitan dengan kehidupan emosional seseorang. Melalui cara emosional, aspek simpati dan empati seseorang dapat digugah. Berdasarkan teori komunikasi persuasif yang bertujuan untuk mengajak, maka program rihlah dalam pelaksanaannya memberikan kontribusi kepada masyarakat untuk mengubah sikap dan perilaku kearah yang lebih baik.

Kontribusi rihlah terhadap organisasi Muhammadiyah adalah semakin berkembanganya organisasi itu sendiri. Hal ini sesuai dengan teori organisasi dimana teori ini membahas tentang bagaimana sebuah organisasi menjalankan fungsi dan mengaktualisasikan visi dan misi organisasi tersebut. Selain itu, dalam teori ini dipelajari bagaimana suatu organisasi memengaruhi dan dipengaruhi oleh orang-orang yang ada di dalamnya, maupun yang berada di lingkungan kerja organisasi tersebut. Menurut Lubis dan Husein teori organisasi adalah sekumpulan ilmu pengetahuan yang membicarakan mekanisme kerjasama dua orang atau lebih secara sistematis untuk mencapai tujuan yang telah ditentukan. Teori organisasi merupakan sebuah teori untuk mempelajari kerjasama pada setiap Individu. Sehingga program rihlah ini memberikan kontribusi terhadap tercapainya visi dan misi organisasi serta semakin eratnya hubungan organisasi dengan masyarakat luas.

Perkembangan sosial merupakan pencapaian kematangan dalam hubungan sosial. Dapat juga diartikan sebagai proses belajar untuk menyesuaikan diri terhadap norma-norma kelompok, moral dan tradisi, meleburkan diri menjadi satu kesatuan dan saling berkomunikasi dan bekerjasama. Menurut Hurlock (2011:250), perkembangan sosial adalah perolehan perilaku yang sesuai dengan tuntutan sosial. Sementara itu Muhbin (Setyadi, 2018) mengatakan bahwa perkembangan sosial 
merupakan proses pembentukan social self (pribadi dalam masyarakat), yakni pribadi dalam keluarga, budaya, bangsa, dan seterusnya .

Berdasarkan teori perkembangan sosial rihlah dalam gerakan dakwah Muhammadiyah membeirkan kontribusi terhadap perkembangan sosial. Perkembangan tersebut dapat diperoleh oleh para partisipan rihlah dalam mengembangan kemamuan berdakwah. Bagi organisasi Muhammadaiyah program rihlah dapat memberikan kontribusi terhadap terlaksanaya program, tercipatanya peta dakwah, semakin dikenalnya organisasi, serta menjadi gambaran untuk meningkatkan pelayanan dakwah kepada masyarakat. Sementara bagi masyarakat khusunya yang menjadi tujuan rihlah, program rihlah memberikan kontribusi terhadap kematangan individu dalam hubungan masyarakat sehingga mampu menyesuaiakn diri terhadap norma-norma kelompok, moral, menjalin kesatuan dan saling berkomunikasi dan berkerjasama berdasarkan ajaran Islam.

\section{PENUTUP}

Hasil penelitian ini menunjukan bahwa rihlah dalam gerakan dakwah Muhammadiyah adalah salah satu program dakwah Muhammadiyah dalam bentuk safari dakwah mubaligh-mubaligh Muhammadiyah ke daerah-daerah untuk saling bertukar informasi, mengenai pelaksanaan tugas dakwah para pimpinan Muhammadiyah, dan upaya mengenalkan organisasi muhammadiyah kepada masyarakat luas dengan cara lawatan, mengunjungi atau bersilaturahim. Dijadikannya rihlah sebagai salah satu Program Dakwah dalam Gerakan dakwah Muhammadiyah Jawa Barat adalah karena perlunya mengembangkan jaringan dakwah kelembagaan, dari tingkat daerah, kecamatan sampai ke desa/kelurahan, perlunya melakukan pendekatan persuasif kepada jama'ah Muhammadiyah dalam menyampaikan pesan dakwah, sehingga da'i dan muballigh Muhammadiyah memiliki militansi serta kompetensi dakwah dalam kultur masyarakat yang heterogen. Pelaksanaan Rihlah Dakwah Muhmadiyah Jawa Barat dilakukan melalui tahapan perencaan, pelaksanaan, hasil dan evaluasi pelaksanaan program rihlah. Strategi yang digunakan dalam program rihlah bervariasi, menyesuaikan dengan keadaan masyarakat pada daerah tujuan rihlah. Program rihlah sangat memberikan kontribusi terhadap tersedianya informasi mengenai potensi, peluang dan tantangan dakwah Muhammadiyah di Jawa Barat.

Penelitian ini memberikan saran kepada prodi KPI agar mempublikasikan penelitian ini pada media publikasi yang ada, dengan begitu akan semakin banyak mahasiswa calon peneliti yang bisa menjadikan penellitian ini sebgai referensi lanjutan. Sangat disarankan kepada peneliti selanjutnya untuk meneliti Rihlah dalam gerakan dakwah Muhammadiyah 
melalui pendekatan penelitian kuantitatif, sehingga dapat diukur efektifitas program rihlah dalam gerakan dakwah Muhammadiyah. Penelitian ini dapat menjadi salah satu sumber informasi bagi Muhammadiyah mengenai perlunya mengembangkan program rihlah, tidak hanya sebatas kunjungan formal yang dilakukan oleh pimpinan organisasi dari level kepengurusan yang lebih tinggi kepada pimpinan persyarikatan tetapi juga sebagai program yang diperuntukan bagi masyarakat luas, sehingga peta dakwah yang didapatkan dari hasil rihlah, tidak hanya memetakan potensi dan peluang dakwah di intern muhammadiyah semata, tetapi juga memetakan potensi peluang dan tantangan dakwah umat Islam secara keseluruhan.

\section{DAFTAR PUSTAKA}

Abdul Majid. (2013), Strategi Pembelajaran. Bandung: PT Remaja Rosdakarya Abdulah Rosyad Shaleh, Manajemen Dakwah. Jakarta: Pustaka 1977, h. 18

Abdurrahman Ahmad As-Sirbuny,Kupas Tuntas Jama'ah Tabligh, Cirebon: Pustaka Nabawi, 2012,Hlm. 147

Ahmad Rifai . Dinamika Gerakan Dakwah Jamaah Muhammadiyyah Kota Bandung: Tesis Sarjana KPI. Bandung: Perputakaan Pascasarjana UIN Sunan Gunung Djati, 2011.

An Nadr M Ishaq Shahab. Khuruj Fisabilillah; Sarana Tabiyyah Ummat Untuke Membentuk Sifat Imaniyyah. Bandung: Al Islah Perss, 2012, th.

Arni Muhammad, Komunikasi Organisasi, Jakarta: PT. Bumi Aksara, 2005), hal. 65

Arsyad Azhar, Pokok-Pokok Manajemen, Yogyakarta; Pustaka Pelajar, 2003, hlm. 26

Depdikbud. 1994. Kurikulum Pendidikan Dasar (GBPP). Depdikbud, Jakarta hal, 984.

Dr. H. Zulkarnain, SH., MH Ketua PW. Muhammadiyah Jawa Barat

Fakhruroji. Dakwah di Era Media Baru, Bandung, h, 6.

Harifudin Cawidu, Konsep Kufr Dalam al-Qur'an, Suatu Kajian Teologis Dengan Pendekatan Tematik (Jakarta: Bulan Bintang, 1991), h. 13.

Ibn Taimiyah, Manhaj Dakwah Salafiyah, pent. Amiruddin, dari judul asli, alAmru bi al-Ma'rûf wa al-Nabyi 'an al-Munkar, Jakarta: Pustaka Azzam, 2001, h. 13.

Kuncoro Mudrajat, Strategi; Bagaimana Meraih Keunggulan Kompetitif, Jakarta, Erlangga, 2005, hlm.1

Lubis, Hari. S.B. dan Martani Husaini. 1987. Teori Organisasi (Suatu Pendekatan Makro). Jakarta: Pusat Antar Universitas Ilmu-ilmu Sosial Universitas Indonesia

Lubis, Hari. S.B. dan Martani Husaini. 1987. Teori Organisasi (Suatu Pendekatan Makro). Jakarta: Pusat Antar Universitas Ilmu-ilmu Sosial 
Universitas Indonesia

M. Ali Aziz, Ilmu Dakwah, Jakarta: Kencana, 2004, h. 37.

Mudjia Rahardjo. Studi Kasus dalam Penelitian Kualitatif; Konsep dan Prosedur..

(Malang: UIN Maulana Malik Ibrahim, 2017).3

Noor Rohman Fauzan dan ahmad Nurisman.Jurnal an-nida:jurnal komunikasi islam..2014

Pimay, Awaludin, Paradigma Dakwah Humanis; Strategi dan Metode Dakwah Prof. KH. Saifudin Zubri, Semarang, Rasail, 2005, hlm.68

Pimpinan Pusat Muhammadiyah, Anggaran Dasar dan Anggaran Rumab Tangga

Muhammadiyah .Yogyakarta: PP. Muhammadiyah, 2002, h. 3.

Samsul Munir Amin, 2009, Ilmu Dakwah, Jakarta, Amzah, hlm, 109-110

Setyadi. 2018. Teori Perkembangan Sosial. Surakarta: Universitas Muhammadiyah Surakarta

Surjadi, Dakwah Islam dengan Pembangunan Masyarakat Desa. Bandung, Mandar Maju, 1989, hlm. 86

Wiryanto, Pengantar Ilmu Komunikasi (Jakarta: PT. Grasindo, 2004), hal. 54.

Yusuf Abdullah Puar, Pejuangan dan Pengabdian Muhammadiyah. Jakarta:

Pustaka Antara, 1989, h. 52

Zainal Arifin. (2012) Evaluasi Program. Bandung, Fakultas IImu Pendidikan UPI 
H. Rustandi, N. Mahendrawaty, \& M. Fakhruroji 